\title{
MAYFLIES IN THE SOUTH SASKATCHEWAN RIVER; POLLUTION INDICATORS
}

\author{
by D. M. Lehmkuhl, University Biology Department, Saskatoon
}

Man has always been attracted to rivers; they often provide the first travel routes into new areas and when settlements are established rivers are a source of water and at the same time a means for disposal of sewage and wastes. Through the construction of reservoirs, rivers are now more important than ever as a source of energy and water for irrigation. Yet, it is only recently that scientists have been making studies of the rivers of the world. The results show that most rivers were destroyed in an ecological sense long before these studies began. It appears, however, that some portions of the Saskatchewan River remain in a state near to the original. It further appears that the insect fauna (based on studies of the Ephemeroptera) may be unique in North America, not because these communities were never found elsewhere, but because the rivers have been destroyed elsewhere. The purpose of this report is to document some facts concerning the mayfly fauna of the South Saskatchewan River, to report some observations on the present state of the river, and to emphasize the extreme vulnerability of the river fauna.

Much taxonomic work remains to be done on the mayflies of the South Saskatchewan River; therefore, the discussion which follows gives families and genera but does not attempt to give species names. The classification and arrangement used here follows that of Edmunds and Allen (1957).

\section{Family Siphlonuridae}

Two genera are present, one of which is a new genus presently being described by G. F. Edmunds, Jr. of the University of Utah. This new mayfly is unusual because it is a carnivore. Edmunds (1957) states that there are four genera in N.A. which are carnivorous and all are exceedingly rare in collections and probably rare in nature. As will be seen, three genera of car- nivorous nymphs are found in the South Saskatchewan. Isonychia is abundant in some areas in the river, and it is a specialized filter feeder which has a comb of setae on the front legs which stain detritus from the water.

\section{Family Oligoneuriidae}

The genus Lachlania occurs in tropical regions (Cuba, Guatemala, Ecuador), in Utah, and in Saskatchewan (Ide, 1941; Edmunds, 1951, and Burks, 1954). Until the past summer this genus from Saskatchewan was represented by a single specimen, this being the type specimen of Lachlania saskatchewanensis Ide. Numerous specimens have now been collected in one locality. The genus is ecologically interesting because it is a filter feeder with behaviour and morphology similar to Isonychia.

\section{Family Heptageniidae}

All members of this family are strongly flattened dorso-ventrally. The genera Stenonema and Heptagenia are widespread in N.A. and both are represented by one or more species in the river. Epeorus, typically a mountain form, is represented by one species. Pseudiron is of interest because it is a predator and it is also considered to be rare. It has extremely long tarsal claws and the nymph moves crab-like over submerged sand bars. A fourth member of this family, Anepeorus, is "an extremely rare form" (Burks, 1953). It was considered extinct by some authorities and until collections were made from the river only about three specimens of nymphs were known. This mayfly, which is a predator, is quite abundant in some areas.

\section{Family Ametropodidae}

Ametropus is considered to be a "rare" mayfly but it is very abundant in the river. It lives in shifting sand, has long middle and hind tarsal claws for anchorage, and the claws of the front legs are specialized for a type of 
filter feeding. Siphloplecton has similarly modified tarsal claws but this mayfly is found in areas of slow water along the shore.

\section{Family Baetidae}

This family is represented in the river by a number of genera, including Baetis, Callibaetis, Centroptilum, Cloeon, and Pseudocloeon. These are all herbivorous, have a streamlined "bullet" shaped body, and are excellent swimmers.

\section{Family Leptophlebiidae}

Choroterpes and Traverella are two unusual but not rare forms which are found in slow areas along the edges of the river.

\section{Families Ephemerellidae and Tricory thidae}

The herbivorous genus Ephemerella is represented in the river by at least one species and several species of Tricorythodes are present.

\section{Family Caenidae}

Saskatoon is the type of locality of the species of Brachycercus found in the river. Caenis is also present. The last four genera are normally found

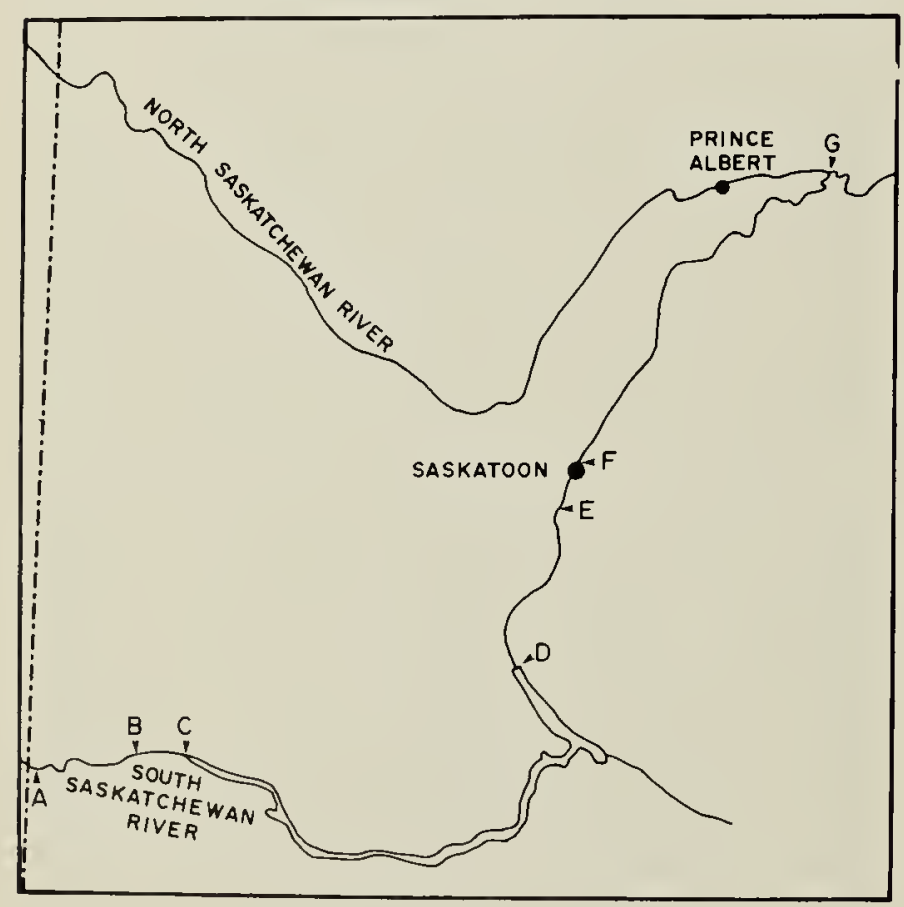

Figure 1. Saskatchewan River System. Zone A-C, "normal". Point C, beginning of Diefenbaker Lake. Zone C-D, lake fauna rather than river fauna. Zone D-E, downstream area influenced by reservoir. Zone E-F, area of partial recovery. Point $F$, entrance of sewage, mercury, etc. Point G, Pulp Mill effluent enters system. See text for further information. crawling in the silt and sediments in areas of slow water along the shore.

\section{Families Ephemeridae and Poly mitarcidae}

Hexagenia and Ephemera (Ephemeridae), and Ephoron (Polymitarcidae), have highly modified body forms adapted to burrowing and feeding in river sediments.

\section{Family Baetiscidae}

There are few records of this family in western N.A. (Edmunds, 1960), but one species has been collected in abundance in the river. In Baetisca, the thorax has expanded posteriorally so that it covers part of the abdomen and there are curious lateral thoracic spines which probably serve as protection against predators.

For the biologist interested in mayflies, certain of the above could be considered a "find of a lifetime" (e.g., Anepeorus). But to find the combination of rare forms, the large number of genera, and the high degree of specializaton shown by some of them indicates that the river is truly unusual.

\section{The River}

The South Saskatchewan River is formed by the confluence of the Bow and Oldman Rivers in Alberta and also receives the waters of the Red Deer River near the Saskatchewan-Alberta border. A number of cities contribute wastes to this drainage system so that even at point B (Figure 1) the system is not entirely free from disturbance. All of the mayflies discussed in the previous section may be collected at point B (Lemsford Ferry) and it is assumed that this fauna is distributed throughout zone A-C. Point $\mathrm{C}$ is the end of the backwater from Gardiner Dam, and in Zone C-D, as would be expected, a specialized river fauna cannot exist, since the area is ecologically a lake and not a river. With possibly one or two exceptions (e.g. Callibaetis) all of the mayflies discussed above are absent in zone C-D.

The effect downstream from the dam is more surprising. Zone $\mathrm{D}-\mathrm{E}$ had a very impoverished mayfly fauna when a survey was made, and a possible reason is that on the date of the survey (June 


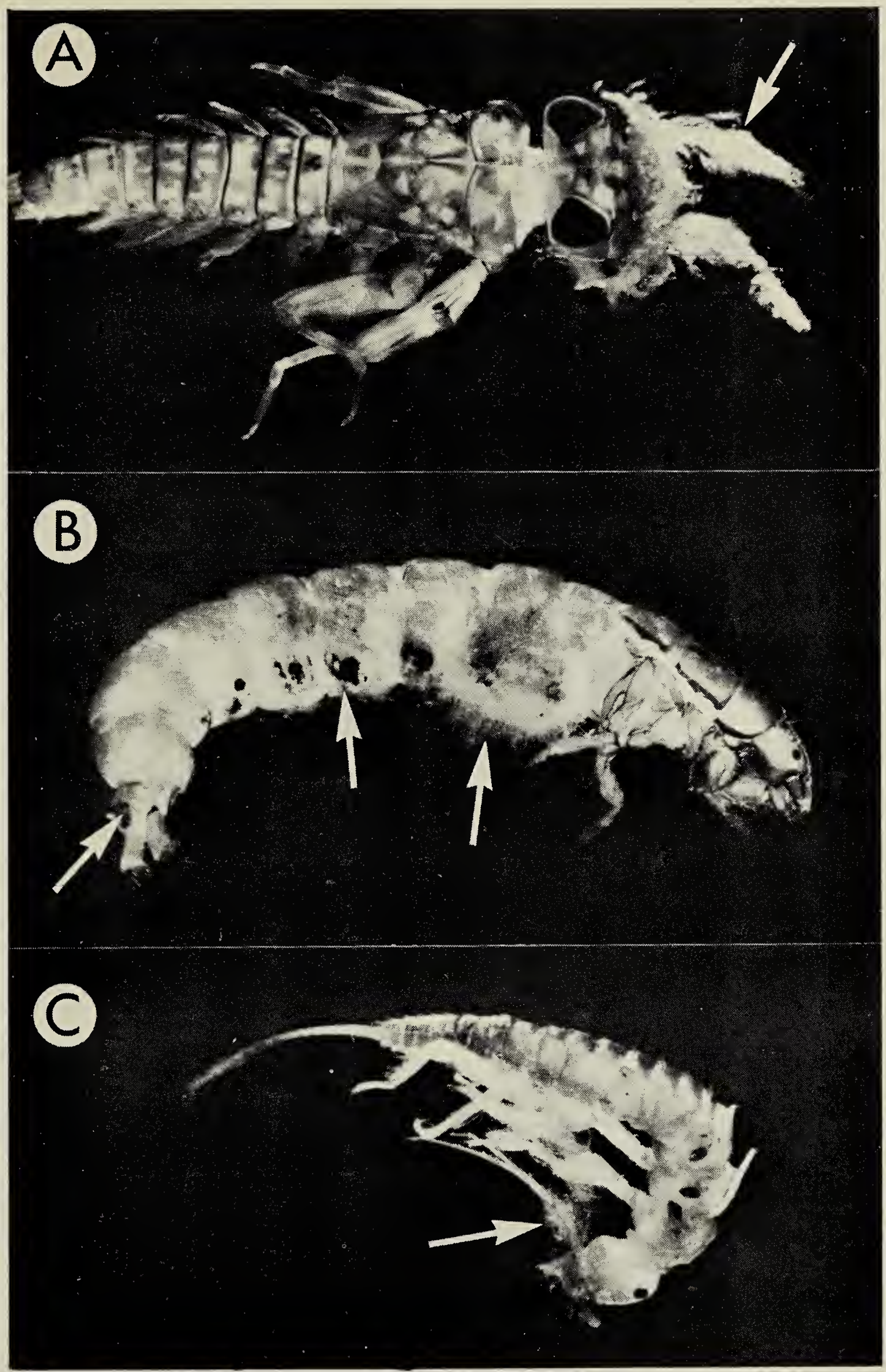

Figure 2. Abnormal specimens collected approximately 5 miles downstream from Saskatoon. A-fungal growth on head and antennae of a mayfly (Heptagenia sp.) B-larva of a caddisfly (Trichoptera: Hydropsychidae). Two arrows to the left show "burned" scars where large fleshy translucent branched gills should be located. Arrow to the right shows fungal growths on the body of the larva. C-Stonefly nymph (Plecoptera) which failed to moult properly. Arrow shows the partly moulted exoskeleton. These specimens, although "alive" when collected, are undoubtedly ecologically dead. 
$4,1970)$ the water at the outflow from Gardiner Dam was $10^{\circ} \mathrm{C}$ colder than the normal river temperature. This low temperature is apparently due to the fact that water forming the outflow is taken from $100+$ feet below the surface of the reservoir. The reservoir stratifies in typical lake fashion (cold waters form the bottom layers, warmer water forms the top as a result of the relationship between density and temperature), and the resulting low temperature of the outflow could be sufficient to inhibit proper development and reproduction of many species.

At point $E$, the water is again of normal temperature, and this corresponds to the reappearance of several species. Zone E-F represents a region of partial, but by no means complete, recovery of the original fauna. Conspicuous because of their absence are the new genus Isonychia, Lachlania, Epeorus, Anepeorus, Choroterpes, Traverella, and Baetisca. In other words the most highly specialized and unusual genera are absent in this zone of partial recovery.

At point $F$, sewage, mercury, etc., are dumped into the river. Most species are eliminated and the fauna downstream from Saskatoon consists mostly of sewage bacteria and sewage worms (Chironomidae and Tubifex). Some insects drift into the area from upstream and their fate is illustrated in Figures 2 a-c.

Information is not available at present to indicate when or if the river recovers downstream from Saskatoon. Although some species undoubtedly return, it is almost certain that the specialists are eliminated. Pulp mill effluent originating from near Prince Albert enters the system at point G (Tones, 1970).

\section{LITERATURE CITED}

Burks, B. D. 1953. The Mayflies, or Ephemeroptera, of Illinois. Bull. Illinois Nat. Hist. Survey 26(1) :1-216.

Edmunds, George F. Jr. 1951. New species of Utah mayflies. I. Oligoneuriidae (Ephemeroptera). Proc. Ent. Soc. Wash. 53 :327-331.

Edmunds, George F. Jr. 1957. The predaceous mayfly nymphs of North America. Proc. Utah Acad. Sci., Arts, Letters 34:23-24.

Edmunds, George F. Jr. 1960. The mayfly genus Baetisca in western North America. Pan-Pacific Entom. $36: 102-104$.

Edmunds, George F. Jr., and R. K. Allen. 1957. A checklist of the Ephemeroptera of North America north of Mexico. Annals Ent. Soc. Amer. $50: 317-324$.

Ide. F. P. 1941. Mayflies of two tropical genera, Lachlania and Campsurus, from Canada with descriptions. Canad. Entom. $73: 153-156$.

Tones, Patricia. 1970. Pollution in the North Saskatchewan River. The Blue Jay 28:111113.

\section{Letters and Notes}

\section{JOHN MACOUN}

Reading the article by C. D. Bird in the September Blue Jay on John Macoun and his travels on the prairies reminded me that in addition to being a botanist Macoun was also something of a politician.

Macoun was the man commissioned by the Canadian government to suggest a route for the proposed transcanada railway line that would cover the most fertile areas of the west. This was in the years 1879 and 1880 .

The prairie country at that time was not altogether unknown, as 20 years earlier it had been explored by Palliser's party, which made two topographical designations: the "arid belt" and the "fertile belt", the former, roughly speaking, being the region south of the confluence of the Red Deer River and the South Saskatchewan. Macoun had also reported on the country between Fort Garry and Edmonton in 1872, and his report confirmed the findings of Palliser as to the richness of the northern section of the country. In the light of this previous knowledge of the country, a justifiable criticism can be made of Macoun's support of the southern railway route. This point is clearly made in an article by Dr. F. G. Roe in the Canadian Historical Review (Vol. 27, June, 1946): "Up to 1881 Macoun might have passed for an unbridled enthusiast who, starting with the Peace River country in the north and working farther southward in successive explora- 